\title{
Twenty Years or More
}

National Cancer Institute

\section{Source}

National Cancer Institute. Twenty Years or More. NCI Thesaurus. Code C148661.

An indication that something has lasted, or occurred during, 20 years or more. 